\title{
Article
}

\section{The German Twin Family Panel (TwinLife)}

\author{
Bastian Mönkediek ${ }^{1}$, Volker Lang ${ }^{1}$, Lena Weigel ${ }^{1}$, Myriam A. Baum², Eike F. Eifler ${ }^{3}$, Elisabeth Hahn², Anke Hufer ${ }^{3}$, \\ Christoph H. Klatzka ${ }^{2}$, Anita Kottwitz ${ }^{1}$, Kristina Krell ${ }^{1}$, Amelie Nikstat ${ }^{3}$, Martin Diewald ${ }^{1}$, Rainer Riemann ${ }^{3}$ and \\ Frank M. Spinath ${ }^{2}$ \\ ${ }^{1}$ Faculty of Sociology, Bielefeld University, Bielefeld, Germany, ${ }^{2}$ Department of Psychology, Saarland University, Saarbrücken, Germany and ${ }^{3}$ Faculty of \\ Psychology and Sport Science, Bielefeld University, Bielefeld, Germany
}

\begin{abstract}
The German Twin Family Panel (TwinLife) is a German longitudinal study of monozygotic and dizygotic same-sex twin pairs and their families that was designed to investigate the development of social inequalities over the life course. The study covers an observation period from approximately 2014 to 2023. The target population of the sample are reared-together twins of four different age cohorts that were born in $2009 /$ 2010 (cohort 1), in 2003/2004 (cohort 2), in 1997/1998 (cohort 3) and between 1990 and 1993 (cohort 4). In the first wave, the study included data on 4097 twin families. Families were recruited in all parts of Germany so that the sample comprises the whole range of the educational, occupational and income structure. As of 2019, two face-to-face, at-home interviews and two telephone interviews have been conducted. Data from the first home and telephone interviews are already available free of charge as a scientific use-file from the GESIS data archive. This report aims to provide an overview of the study sample and design as well as constructs that are unique in TwinLife in comparison with previous twin studies - such as an assessment of cognitive abilities or information based on the children's medical records and report cards. In addition, major findings based on the data already released are displayed, and future directions of the study are presented and discussed.
\end{abstract}

Keywords: Extended twin family design; register sample; social inequality; twin study

(Received 13 May 2019; accepted 17 June 2019; First Published online 10 September 2019)

\section{Overview, Design and Sample Description}

In contrast to many other countries (e.g., the Netherlands; Boomsma et al., 2006), no twin registry is available for Germany. Previous efforts to collect twin data have not used probability-based sampling designs or have only focused on specific regions (Busjahn, 2013; Hahn et al., 2013; Kandler et al., 2013). The German Twin Family Panel, 'TwinLife', closes this gap by collecting longitudinal data on, in the first wave, 4097 families with monozygotic or same-sex dizygotic twin children (Diewald et al., 2019). As of 2019, two face-to-face, at-home interviews and two telephone interviews have been conducted. The planned observation period comprises 10 years (between 2014 and 2023). TwinLife is the first twin (family) panel in Germany implementing a population register-based sampling design, which allows for reliable comparisons with twin data from other countries. Additionally, TwinLife covers all parts of the country and includes the whole range of the educational, occupational and income structure (Lang \& Kottwitz, 2017). Capturing the lower and upper bounds of these social structural characteristics is especially important for TwinLife because these extremes are particularly relevant for the analysis of differential genetic and environmental influences on traits.

Author for correspondence: Bastian Mönkediek, Email: bastian.moenkediek@unibielefeld.de

Cite this article: Mönkediek B, Lang V, Weigel L, Baum MA, Eifler EF, Hahn E, Hufer A, Klatzka CH, Kottwitz A, Krell K, Nikstat A, Diewald M, Riemann R, and Spinath Frank M. (2019) The German Twin Family Panel (TwinLife). Twin Research and Human Genetics 22: 540-547, https://doi.org/10.1017/thg.2019.63
As the data collection was performed only in German, TwinLife is restricted to families with good proficiency of the German language.

The target population of TwinLife consists of four age cohorts with twins aged 5 (cohort 1), 11 (cohort 2), 17 (cohort 3 ) and 23-24 (cohort 4) at the time of the first survey (2014/2015). Taken together, the cohorts cover the major developmental transition phases of childhood, adolescence and young adulthood over the course of the study (Hahn et al., 2016). For example, the youngest twins (cohort 1) were interviewed for the first time prior to school entry. In the course of the planned study duration, they will experience all transitions in the educational system until the end of secondary schooling. The oldest twins (cohort 4) are observed for the first time prior to or shortly after leaving the parental home and pursuing tertiary education or establishing themselves in the labor market. For them, the study covers the typical life phase for family formation and early career employment.

The TwinLife study combines this cohort-sequential design with an extended twin family design (ETFD). As part of the ETFD, the biological and, if applicable, the social parents (i.e., partners of mothers or fathers) as well as the sibling who is closest in age to the twins (and at least 5 years old) are surveyed in addition to the twins themselves. Moreover, the partners of adult twins - if available - are included in the sample, too. Compared to the classical twin design, the ETFD enables a better assessment of family influences on the children's development, as well as more precise estimates of genetic transmission (Keller et al., 2010). Further, the ETFD design entails collecting data from multiple

(c) The Author(s) 2019. This is an Open Access article, distributed under the terms of the Creative Commons Attribution-NonCommercial licence (http://creativecommons.org/licenses/ by-nc/4.0/), which permits unrestricted re-use, distribution, and reproduction in any medium, provided the original work is properly cited. 
Table 1. Families in the first two home and the first telephone interviews of TwinLife ${ }^{a}$

\begin{tabular}{|c|c|c|c|c|c|}
\hline & Cohort $1(\%)$ & Cohort 2 (\%) & Cohort $3(\%)$ & Cohort $4(\%)$ & Total (\%) \\
\hline \multicolumn{6}{|l|}{ First home interview } \\
\hline Monozygotic, male & $210(20.8)$ & $191(18.3)$ & $218(20.6)$ & $213(21.7)$ & $832(20.3)$ \\
\hline Monozygotic, female & $225(22.3)$ & $230(22.1)$ & $280(26.4)$ & $311(31.6)$ & $1046(25.5)$ \\
\hline Dizygotic, male & $280(27.8)$ & $309(29.6)$ & $235(22.2)$ & $198(20.1)$ & $1022(25.0)$ \\
\hline Dizygotic, female & $292(28.9)$ & $311(29.8)$ & $327(30.8)$ & $260(26.5)$ & $1190(29.1)$ \\
\hline No zygosity information & $3(0.3)$ & $2(0.2)$ & $1(0.1)$ & $1(0.1)$ & $7(0.2)$ \\
\hline Total & $1010(100.0)$ & $1043(100.0)$ & $1061(100.0)$ & $983(100.0)$ & $4097(100.0)$ \\
\hline \multicolumn{6}{|l|}{ First telephone interview } \\
\hline Monozygotic, male & $142(19.9)$ & $138(18.5)$ & $162(20.3)$ & $155(21.6)$ & $597(20.1)$ \\
\hline Monozygotic, female & $162(22.7)$ & $159(21.3)$ & $213(26.7)$ & $224(31.2)$ & $758(25.5)$ \\
\hline Dizygotic, male & $193(27.1)$ & $224(30.0)$ & $187(23.5)$ & $147(20.5)$ & $751(25.2)$ \\
\hline Dizygotic, female & $216(30.3)$ & $225(30.1)$ & $235(29.5)$ & $192(26.7)$ & $868(29.2)$ \\
\hline No zygosity information & - & $1(0.1)$ & - & $1(0.1)$ & $2(0.1)$ \\
\hline Total & $713(100.0)$ & $747(100.0)$ & $797(100.0)$ & $719(100.0)$ & $2976(100.0)$ \\
\hline \multicolumn{6}{|l|}{ Second home interview } \\
\hline Monozygotic, male & $150(20.0)$ & $144(19.1)$ & $133(20.2)$ & $129(21.8)$ & $556(20.2)$ \\
\hline Monozygotic, female & $166(22.2)$ & $169(22.4)$ & $180(27.4)$ & $179(30.2)$ & $694(25.2)$ \\
\hline Dizygotic, male & $212(28.3)$ & $229(30.3)$ & $143(21.7)$ & $124(20.9)$ & $708(25.7)$ \\
\hline Dizygotic, female & $220(29.4)$ & $212(28.0)$ & $202(30.7)$ & $160(27.0)$ & $794(28.8)$ \\
\hline No zygosity information & $1(0.1)$ & $2(0.3)$ & - & $1(0.2)$ & $4(0.2)$ \\
\hline Total & $749(100.0)$ & $756(100.0)$ & $658(100.0)$ & $593(100.0)$ & $2756(100.0)$ \\
\hline
\end{tabular}

Note: ${ }^{\text {a }}$ Reported sample sizes and participation rates are defined by at least one family member participating in the respective survey.

Source: TwinLife (doi: 10.4232/1.13208), own calculations

informants per family. To shorten the time interviewers spent in a household, a combination of different survey modes was employed in the face-to-face interviews: computer-assisted personal interviews, computer-assisted self-interviews and paper and pencil interviews (Brix et al., 2017).

The target sample size for the first home interview was 1000 twin families in each of the four cohorts sampled from the official registries of residents of 500 communities with more than 5000 inhabitants all over Germany. The communities were themselves sampled out of an official registry of communities, listing approximately 11,900 communities. In this context, a purposeful oversampling of larger communities with more than 50,000 residents was necessary to achieve the desired sample size. In each sampled community, registration offices were contacted and potential twin families were identified based on registration information by locating persons of the same sex with the same or similar birth dates registered at the same address (Lang \& Kottwitz, 2017). For the oldest cohort (cohort 4 ), in which twin children potentially already moved out of their parents homes, registries of residents dating several years back were used to identify potential twin families. For more details on the register-based sampling design, see Lang and Kottwitz (2017).

TwinLife includes only same-sex dizygotic twin children, that is, opposite-sex dizygotic twins were not sampled. Focusing on same-sex dizygotic twin children reduced the target sample size of the study and the number of necessary sampling points (communities). In addition, it simplified the identification process of potential twin families. However, in consequence, TwinLife cannot be used to study the effects of within-twin-pair gender differences on phenotypes.
The twin children and their families are interviewed biyearly through face-to-face interviews at the twin families' homes. In the years between the face-to-face interviews, the families are surveyed by telephone. In the first telephone interview, all respondents aged 10 and above who participated in the first home interview and were living with one of the twins, including the twins themselves, were surveyed. Siblings and partners not living with one of the twins were not interviewed. For the twin children in the youngest cohort (cohort 1), and for siblings below the age of 10 , data were collected based on parental reports. Following the selection rules of the first face-to-face interview, in the second home interview all persons aged 5 and above were again surveyed, including the twins of the first birth cohort.

Table 1 shows the sample sizes and participation rates in the first two home interviews and the first telephone interview of TwinLife by cohort, twins' zygosity and gender. Additionally, Figure 1 displays the participation rates by cohort. All sample sizes and participation rates reported in Table 1 and Figure 1 are calculated based on at least one family member participating in the respective survey. Sample sizes and participation rates calculated based on at least one twin in the family participating in the first face-to-face survey are similar to those reported here due to the definition of the target population for TwinLife (see above).

Approximately $45 \%$ of the twin pairs in cohorts $1-3$ and $53 \%$ of the twin pairs in cohort 4 are monozygotic, indicating that the probability-based sampling design worked well to counteract the typically strong overrepresentation of monozygotic twin pairs (Lykken et al., 1987). Approximately $98 \%$ of the families declared 


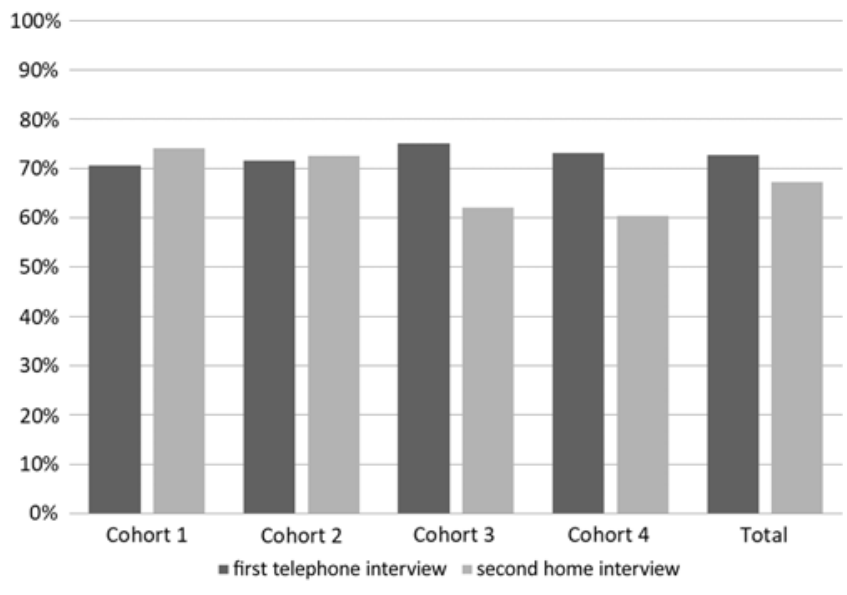

Fig. 1. Participation rates of families in the first two home and the first telephone interviews of TwinLife.

Note: Reported sample sizes and participation rates are defined by at least one family member participating in the respective survey. Source: TwinLife (doi:10.4232/1.13208), own calculations.

their willingness to participate further in the panel after the first home interview. The panel participation rates of these families in the first telephone survey were above $70 \%$ in each cohort, with approximately $5 \%$ permanent refusals (i.e., panel dropouts). Further, in the first telephone survey, no twins were interviewed in the youngest cohort (cohort 1 , see above) and participation rates for the other cohorts calculated based on at least one participating twin per family were about $65 \%$. With respect to the first home interview, the panel participation rates in the second home interview were again above $70 \%$ in the two younger birth cohorts and slightly above $60 \%$ in the two older cohorts. Also, participation rates calculated based on at least one participating twin per family were around $70 \%$ in the younger and around $60 \%$ in the two older cohorts. The lower participation rates in the older cohorts are mostly due to twins moving out of the parental home, making it more difficult to contact them and to schedule interviews.

Given the ETFD and these sample selection rules for the first telephone survey, the sample contains information on 16,954 persons for the first home interview, 8721 persons for the first telephone interview and 10,956 persons for the second home interview. The lower number of persons per family surveyed in the telephone interview is mostly related to not interviewing the twins in cohort 1 (see above).

Data on the first home and telephone interviews are already available free of charge as a scientific use-file at the GESIS data archive via the Data Catalogue (for the current release see: https://doi.org/10.4232/1.13208).

\section{Sample Representativeness}

The TwinLife data are a probability sample based on registries of residents. To assess the representativeness of the TwinLife sample with respect to the social stratification in Germany, Lang and Kottwitz (2017) compared the distributions of parental education and occupational status as well as household income in TwinLife with those of a proxy-twin sample based on the German Microcensus (Destatis, 2014). The German Microcensus is a representative household register sample. Proxy-twin pairs were identified as persons with the same year of birth living in the same household. The analysis showed an approximately 15 percentage points higher share of tertiary-educated households, a slightly higher median household income and mean occupational status, as well as an approximately 10 percentage points lower share of households with no German citizenship in TwinLife. These results indicated that participation in TwinLife was, to some degree, selective, especially regarding parental education. The lower share of households with no German citizenship in TwinLife can account for about a quarter of the differences in household education, income and occupation between TwinLife and the Microcensus. Most importantly, the analysis confirmed the sample's full coverage of the core socioeconomic indicators including the lower and upper bounds.

\section{Zygosity Questionnaire/Determination}

Genotyping zygosity may offer an almost perfect method to determine zygosity, but it comes with certain disadvantages, such as higher costs and a greater burden for participants. In TwinLife, the zygosity of the twins was, therefore, assessed using physical similarity questionnaires (see Goldsmith, 1991; Oniszczenko et al., 1993). In cohorts 1 and 2, the questions were answered by the twins' parents. In cohorts 3 and 4 , the questions were answered by the twins themselves. To assess the accuracy of the classification, zygosity estimation based on the questionnaire was validated by genotyping a subsample of twins $(n=328)$. The results indicate a high validity of questionnaire-based zygosity determination with correct classifications for $97 \%$ of parental reports and $96 \%$ of self-reports (see Lenau et al., 2017).

\section{Overview of the Measurements}

To comprehensively study unequal life chances, the TwinLife study includes a wide range of constructs, some of which have rarely been addressed in previous longitudinal studies (for an overview, see Table 2). The constructs cover six domains of social inequality (see Figure 2): (1) skill formation and education, (2) career and labor market attainment, (3) political and social integration and participation, (4) subjective perception of quality of life, (5) physical and psychological health and (6) deviant behavior and behavioral problems. A detailed overview of all available constructs is provided online at the TwinLife page of the GESIS Data Catalogue (https://doi.org/10.4232/1.13208). Moreover, the constructs cover important information about different life course transitions, ranging from school to labor market entry, and other important life course events, such as mating and starting a family. To make use of the panel design and to compare results with those from other large-scale panel studies, TwinLife often uses the same constructs and measurements that are used in other representative family or household samples that are not twin-based, such as the German Socio-Economic Panel (SOEP; Goebel et al., 2018) and the German Family Panel (Pairfam; Brüderl et al., 2018; Huinink et al., 2011).

\section{Assessment of Cognitive Ability}

TwinLife includes an assessment of cognitive ability and uses the Culture Fair Test to measure nonverbal (fluid) intelligence as a proxy for general cognitive ability (CFT; Weiß, 2006; Weiß \& Osterland, 2012). Three different subtests (figural reasoning, figural classification and matrices) were administered to children aged 5-9. For participants aged 10 years and older, four subtests were used (reasoning in addition to the aforementioned three). For the younger group, the test was applied in a paper-and-pencil 
Table 2. Summary of measures collected for the German Twin Family panel (TwinLife)

\begin{tabular}{|c|c|c|c|c|c|c|c|c|c|c|c|c|c|c|c|c|c|c|c|c|c|c|}
\hline & \multirow[b]{2}{*}{ Constructs } & \multicolumn{7}{|c|}{$\mathrm{F} 2 \mathrm{~F} 1$} & \multicolumn{7}{|c|}{ CATI 1} & \multicolumn{7}{|c|}{ F2F 2} \\
\hline & & Age & Twins & Parents & Siblings & Partner & $\mathrm{HH}$ & $\begin{array}{l}\text { No. } \\
\text { of } \\
\text { items }\end{array}$ & Age & Twins & Parents & Siblings & Partner & $\mathrm{HH}$ & $\begin{array}{l}\text { No. } \\
\text { of } \\
\text { items }\end{array}$ & Age & Twins & Parents & Siblings & Partner & $\mathrm{HH}$ & $\begin{array}{l}\text { No. } \\
\text { of } \\
\text { items }\end{array}$ \\
\hline \multirow{10}{*}{$\begin{array}{l}\text { Skill Formation and } \\
\text { education }\end{array}$} & $\begin{array}{l}\text { Cognitive } \\
\text { development }\end{array}$ & $<12$ & $\mathrm{p}, \mathrm{i}$ & & $\mathrm{p}, \mathrm{i}$ & & & 36 & & & & & & & & $\leq 15$ & $\mathrm{p}$ & & $\mathrm{p}$ & & & 19 \\
\hline & $\begin{array}{l}\text { Educational success } \\
\text { and educational } \\
\text { attainment }\end{array}$ & & s & s & s & s & & 129 & & $s, p$ & s & $s, p$ & & & 8 & & $s, p$ & s & $s, p$ & s & & 105 \\
\hline & Intelligence & & s & s & s & s & & 228 & & & & & & & & & & & & & & \\
\hline & Media use & & s & s & s & s & & 11 & & & & & & & & & $s, p$ & s & $s, p$ & s & & 11 \\
\hline & Motivation & & s & s & s & s & & 46 & & & & & & & & & $\mathrm{~s}, \mathrm{p}$ & s & $s, p$ & s & & 39 \\
\hline & Personality & & $s, p$ & $\mathrm{~s}$ & $s, p$ & s & & 29 & & & & & & & & & s & s & $s, p$ & $\mathrm{~s}$ & & 32 \\
\hline & $\begin{array}{l}\text { Private tutoring/ } \\
\text { Utilization of special } \\
\text { support }\end{array}$ & $<16$ & s & & s & & & 17 & & & & & & & & & & & & & & \\
\hline & Self-efficacy & $\geq 10$ & s & s & s & s & & 3 & & & & & & & & $\geq 10$ & s & s & s & s & & 3 \\
\hline & Self-esteem & & $s, p$ & s & $s, p$ & s & & 4 & & & & & & & & & $s, p$ & s & $s, p$ & s & & 5 \\
\hline & Self-regulation & & & & & & & & & $s, p$ & s & $s, p$ & & & 7 & & $s, p$ & & $s, p$ & $\mathrm{~s}$ & & 26 \\
\hline \multirow{3}{*}{$\begin{array}{l}\text { Career, labor } \\
\text { market attainment } \\
\text { and welfare }\end{array}$} & $\begin{array}{l}\text { Employment status of } \\
\text { household members }\end{array}$ & & & & & & s & 19 & & & & & & & & & & & & & $\mathrm{~s}$ & 300 \\
\hline & $\begin{array}{l}\text { Employment status } \\
\text { and current position }\end{array}$ & $\geq 16$ & s & s & s & s & & 50 & $\geq 15$ & s & s & s & & & 17 & $\geq 15$ & s & s & s & s & & 38 \\
\hline & $\begin{array}{l}\text { Wages, welfare } \\
\text { dependency }\end{array}$ & $\geq 16$ & s & s & s & s & & 31 & $\geq 16$ & s & s & s & & s & 4 & $\geq 15$ & s & s & s & s & & 31 \\
\hline \multirow[t]{7}{*}{$\begin{array}{l}\text { Integration and } \\
\text { participation }\end{array}$} & $\begin{array}{l}\text { Experiences of } \\
\text { discrimination }\end{array}$ & $\geq 13$ & s & $\mathrm{s}$ & $\mathrm{s}$ & $\mathrm{s}$ & & 14 & & & & & & & & $\geq 13$ & $\mathrm{~s}$ & $\mathrm{~s}$ & $\mathrm{~s}$ & $\mathrm{~s}$ & & 17 \\
\hline & $\begin{array}{l}\text { Migration and } \\
\text { citizenship }\end{array}$ & & $s, p$ & s & $s, p$ & s & & 13 & & & & & & & & & $s, p$ & s & $s, p$ & s & & 18 \\
\hline & Political participation & & s & s & s & s & & 7 & & & & & & & & $\geq 10$ & $\mathrm{~s}$ & $\mathrm{~s}$ & $\mathrm{~s}$ & $\mathrm{~s}$ & & 7 \\
\hline & Religion & & & & & & & & & $s, p$ & s & $s, p$ & & & 4 & & & & & & & \\
\hline & Social networks & $\geq 15$ & $s, p$ & s & $s, p$ & s & & 21 & & & & & & & & & $\mathrm{~s}, \mathrm{p}$ & s & $s, p$ & s & & 38 \\
\hline & Social participation & & $s, p$ & s & $s, p$ & s & & 9 & & & & & & & & $\geq 13$ & s & s & s & s & & 10 \\
\hline & Cultural capital & & & & & & & & & & & & & & & & $s, p$ & s & $s, p$ & s & & 25 \\
\hline \multirow[t]{6}{*}{ Quality of life } & Affect balance & & & & & & & & & & & & & & & $\geq 10$ & s & s & s & s & & 3 \\
\hline & Burden and stress & & & & & & & & & & & & & & & & s & s & s & s & & 57 \\
\hline & Depression & & & & & & & & & & & & & & & $\geq 10$ & s & s & s & s & & 7 \\
\hline & Life goals & & & & & & & & & & & & & & & $\geq 16$ & s & $\mathrm{s}$ & s & s & & 10 \\
\hline & Life satisfaction & $\geq 10$ & $\mathrm{~s}$ & s & s & s & & 15 & $\geq 10$ & s & s & s & & & 11 & $\geq 10$ & s & s & s & s & & 15 \\
\hline & $\begin{array}{l}\text { Sensory processing } \\
\text { sensitivity }\end{array}$ & & & & & & & & & & & & & & & $\geq 10$ & s & s & s & s & & 12 \\
\hline
\end{tabular}


Constructs

Age Twins Parents Siblings Partner $\mathrm{HH}$ items 77

\begin{tabular}{|c|c|c|c|c|c|c|c|c|c|c|c|c|c|c|c|c|c|c|c|c|c|}
\hline \multirow[t]{9}{*}{ Health } & $\begin{array}{l}\text { Examination reports } \\
\text { ('U-Heft') }\end{array}$ & & s & & $\mathrm{s}$ & & & 77 & & & & & & & & & & & & & \\
\hline & Health behavior & & $s, p$ & s & $s, p$ & s & & 18 & & & & & & & & $s, p$ & s & $s, p$ & s & & 19 \\
\hline & $\begin{array}{l}\text { Measures of height } \\
\text { and weight, body } \\
\text { mass index }\end{array}$ & & $s, p$ & $\mathrm{~s}$ & $s, p$ & s & & 2 & & & & & & & & $s, p$ & $\mathrm{~s}$ & $s, p$ & $\mathrm{~s}$ & & 2 \\
\hline & $\begin{array}{l}\text { Objective health/ } \\
\text { Diagnoses }\end{array}$ & & $s, p$ & s & $s, p$ & s & & 157 & & $s, p$ & s & $s, p$ & & 79 & & $s, p$ & s & $s, p$ & s & & 228 \\
\hline & $\begin{array}{l}\text { Physical } \\
\text { attractiveness }\end{array}$ & & & & & & & & & & & & & & $\geq 10$ & s & s & s & s & & 2 \\
\hline & Pregnancy & & & & & & & & & & & & & & & $\mathrm{p}$ & & $\mathrm{p}$ & & & 19 \\
\hline & Puberty & & & & & & & & & & & & & & $\begin{array}{l}>10 \\
\text { and } \\
\leq 15\end{array}$ & s & s & & & & 4 \\
\hline & Sexual orientation & & & & & & & & & & & & & & $\geq 16$ & s & s & $\mathrm{s}$ & s & & 5 \\
\hline & Subjective health & & $s, p$ & $\mathrm{~s}$ & $s, p$ & $\mathrm{~s}$ & & 1 & & $s, p$ & $\mathrm{~s}$ & $s, p$ & $\mathrm{~s}$ & 1 & & $s, p$ & $\mathrm{~s}$ & $s, p$ & $\mathrm{~s}$ & & 1 \\
\hline \multirow[t]{13}{*}{ Environment } & $\begin{array}{l}\text { (Relationship with/ } \\
\text { information on) } \\
\text { grandparents }\end{array}$ & & s & $\mathrm{s}$ & $\mathrm{s}$ & & & 20 & & & s & & & 36 & & & & & & & \\
\hline & $\begin{array}{l}\text { Childcare and care } \\
\text { characteristics }\end{array}$ & $\leq 6$ & s & s & $\mathrm{s}$ & & & 188 & & & & & & & & & & & & & \\
\hline & Children of twins & & & & & & & & & & & & & & $\geq 16$ & $\mathrm{~s}$ & & $\mathrm{~s}$ & & & 52 \\
\hline & $\begin{array}{l}\text { Contact with other } \\
\text { family members }\end{array}$ & & & & & & & & $\geq 10$ & $s, p$ & s & $s, p$ & & 14 & & $s, p$ & s & $s, p$ & s & & 7 \\
\hline & Family activities & $<16$ & s & s & s & & & 9 & & & & & & & & $s, p$ & & $s, p$ & & & 8 \\
\hline & Family stresses & & & & & & & & & & & & & & & & & & & $\mathrm{s}$ & 34 \\
\hline & $\begin{array}{l}\text { Family structure and } \\
\text { household } \\
\text { characteristics }\end{array}$ & $\geq 10$ & s & s & s & & s & 16 & & & & & & 5 & $\geq 16$ & s & s & s & s & & 8 \\
\hline & Intentional level & & & & & & & & & & & & & & $\geq 15$ & s & & $\mathrm{s}$ & & & 11 \\
\hline & Life events & & & & & & & & & $\mathrm{s}, \mathrm{p}$ & $\mathrm{s}$ & $\mathrm{s}, \mathrm{p}$ & $\mathrm{s}$ & 110 & $\geq 10$ & $\mathrm{~s}$ & $\mathrm{~s}$ & $\mathrm{~s}$ & s & & 151 \\
\hline & Life transitions & & & & & & & & $\geq 8$ & $s, p$ & & $\mathrm{~s}, \mathrm{p}$ & & 13 & & $\mathrm{~s}, \mathrm{p}$ & & $s, p$ & & & 18 \\
\hline & Parenting & & & $\mathrm{s}, \mathrm{C}$ & & & & 51 & & & & & & & $\geq 10$ & & c & & & & 25 \\
\hline & $\begin{array}{l}\text { Quality of home } \\
\text { environment }\end{array}$ & $\geq 10$ & $\mathrm{~s}$ & $\mathrm{~s}$ & $\mathrm{~s}$ & $\mathrm{~s}$ & & 13 & & & & & & & & $\mathrm{~s}$ & & $\mathrm{~s}$ & & $\mathrm{i}$ & 12 \\
\hline & $\begin{array}{l}\text { Sibling relationship } \\
\text { quality }\end{array}$ & & $\mathrm{s}$ & & $\mathrm{s}$ & & & 34 & & & & & & & & $\mathrm{~s}$ & & $\mathrm{~s}$ & & & 22 \\
\hline
\end{tabular}



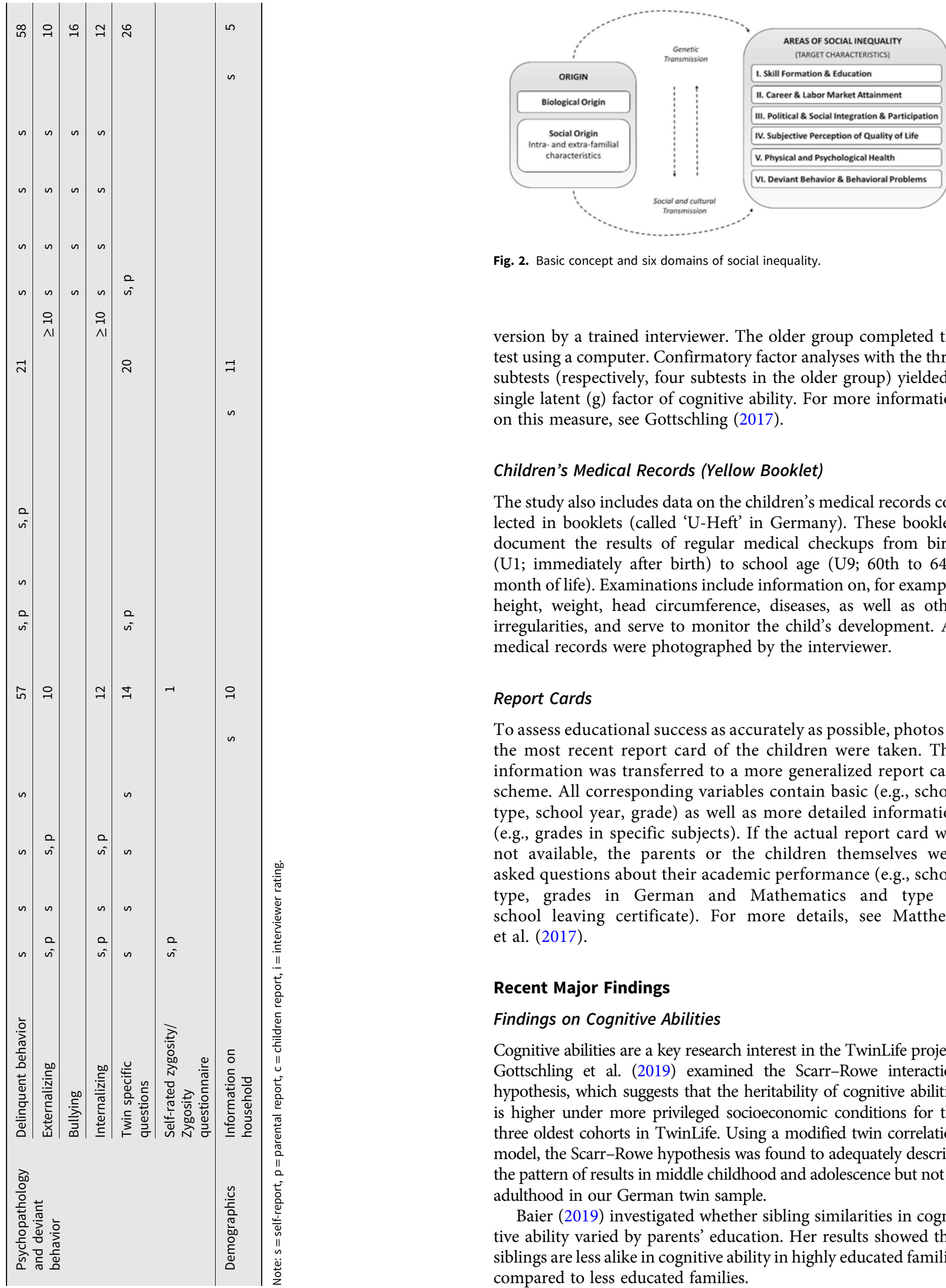

Fig. 2. Basic concept and six domains of social inequality.

version by a trained interviewer. The older group completed the test using a computer. Confirmatory factor analyses with the three subtests (respectively, four subtests in the older group) yielded a single latent (g) factor of cognitive ability. For more information on this measure, see Gottschling (2017).

\section{Children's Medical Records (Yellow Booklet)}

The study also includes data on the children's medical records collected in booklets (called 'U-Heft' in Germany). These booklets document the results of regular medical checkups from birth (U1; immediately after birth) to school age (U9; 60th to 64th month of life). Examinations include information on, for example, height, weight, head circumference, diseases, as well as other irregularities, and serve to monitor the child's development. All medical records were photographed by the interviewer.

\section{Report Cards}

To assess educational success as accurately as possible, photos of the most recent report card of the children were taken. This information was transferred to a more generalized report card scheme. All corresponding variables contain basic (e.g., school type, school year, grade) as well as more detailed information (e.g., grades in specific subjects). If the actual report card was not available, the parents or the children themselves were asked questions about their academic performance (e.g., school type, grades in German and Mathematics and type of school leaving certificate). For more details, see Mattheus et al. (2017).

\section{Recent Major Findings}

\section{Findings on Cognitive Abilities}

Cognitive abilities are a key research interest in the TwinLife project. Gottschling et al. (2019) examined the Scarr-Rowe interaction hypothesis, which suggests that the heritability of cognitive abilities is higher under more privileged socioeconomic conditions for the three oldest cohorts in TwinLife. Using a modified twin correlation model, the Scarr-Rowe hypothesis was found to adequately describe the pattern of results in middle childhood and adolescence but not in adulthood in our German twin sample.

Baier (2019) investigated whether sibling similarities in cognitive ability varied by parents' education. Her results showed that siblings are less alike in cognitive ability in highly educated families compared to less educated families. 


\section{Findings on Educational Outcomes}

As achievement motivation is a prerequisite of educational success, Klassen et al. (2018) investigated its etiology, showing that nonshared environmental factors played a major role, as did additive and nonadditive genetic variance.

Schulz et al. (2017) investigated different 'pathways linking parental socioeconomic position to their children's cognitive ability and academic track attendance in secondary school' (p. 2194). They showed that separate dimensions of socioeconomic resources influenced child cognitive ability, while a child's own cognitive ability, parental cognitive ability and parental socioeconomic resources directly affected the child's track attendance.

Based on twin fixed-effects models, Gil-Hernández (2019) studied whether high socioeconomic status families 'compensate for low cognitive ability in the transition to secondary education in Germany' (p. 150). His results did not provide any evidence for highly educated families compensating for low cognitive ability in their twin children.

Concerning the final educational degree attained, Baier and Lang (2019) found a pattern following the Scarr-Rowe interaction hypothesis for the young adults in the oldest birth cohort of twins. Whereas genetic influences were more important for educational attainment of twins in families with higher educated parents, shared environmental influences mattered more if parental education was low. Moreover, controlling for assortative mating of parents based on their education accounted for a substantial part of the genetic influences on educational attainment.

\section{Findings on Social and Political Integration}

Another current research focus in TwinLife is on social and political integration as an indicator of social inequality. In this vein, Kornadt et al. (2018) analyzed the genetic and environmental sources of variance in political interest and evaluated political and social participation using a nuclear twin family design (NTFD), a specific form of the ETFD. Hufer et al. (2019) further investigated political orientation. These studies provided evidence that political traits are moderately to strongly heritable and that parental environmental transmission is less prominent than often assumed. Additionally, Weinschenk et al. (2019) showed a significant genetic overlap of political engagement, openness and cognitive ability.

\section{Findings on Health}

Johnson et al. (2018) compared influences of parental socioeconomic status on the relative contribution of genetic and environmental factors to body mass index in German and Minnesotan youths. The authors concluded that socioeconomic status moderates genetic influences, especially in females.

\section{Findings on Personality Traits}

Using a NTFD, Bleidorn et al. (2018) found moderate heritability and strong influences of nonshared environmental factors on selfesteem, supporting earlier findings based on a classical twin design. Kandler et al. (2019) demonstrated an increase of genetic variance in Big Five personality traits from late childhood to early adulthood.

\section{Outlook}

\section{Molecular Genetic Extension/Saliva Collection}

Twin studies/registries traditionally rely on comparing monozygotic with dizygotic twin pairs to measure the contributions of genes and environment to a specific trait. However, there are increasing efforts to genotype twins, because molecular genetic data offer additional possibilities for analyzing how genes and environment and their combinations (gene-environment correlation and interaction) influence a specific trait (Boomsma et al., 2002), and this information can easily be integrated in standard social science modeling approaches. Respectively, there is a growing number of twin studies/registries that contain molecular genetic data, such as the Twins Early Development Study (Haworth et al., 2013), the UK Adult Twin Registry (Spector \& Williams, 2006) or the Swedish Twin Registry (Magnusson et al., 2013). In parallel with the face-to-face survey wave 3, which started in 2018, saliva collection kits were given to twins, biological parents and siblings participating in TwinLife. The collection of saliva - in cooperation with the Universitätsklinikum Bonn is part of the third TwinLife funding period, with a goal of adding molecular genetic data to the longitudinal survey data at a later time point. The planned genetic analyses comprise the construction of polygenic scores for a variety of phenotypes relevant to attainment and mobility as well as the computation of genomewide association studies for specific behavioral traits, which form the basis for subsequent single-nucleotide polymorphism-based heritability, genetic correlation and pathway analyses.

\section{Microm}

For particular analyses, the TwinLife sample can be matched with a range of neighborhood-related variables. These include information on spending power, type of building development, type of roads, age structure as well as Sinus-Geo-Milieus (reflecting dominant sociocultural diversity), phases of life, mobility and Microm typologies. The variables were calculated based on data collected by the data research and marketing firm Microm. Prospectively, these data will be accessible by special agreement.

Acknowledgments. The TwinLife Project is funded by the German Research Foundation (DFG) (grant number 220286500) awarded to Martin Diewald, Rainer Riemann and Frank M. Spinath. The TwinLife study ('Genetic and social causes of life chances. A genetically informative, longitudinal study of the life course and individual development') received ethical approval from the German Psychological Association (protocol numbers: RR 11.2009 and RR 09.2013).

\section{References}

Baier, T. (2019). Does sibling and twin similarity in cognitive ability differ by parents' education? Journal of Family Research, 31, 58-82.

Baier, T., \& Lang, V. (2019). The social stratification of environmental and genetic influences on education: New evidence using a register-based twin sample. Sociological Science, 6, 143-171.

Bleidorn, W., Hufer, A., Kandler, C., Hopwood, C. J., \& Riemann, R. (2018). A nuclear twin family study of self-esteem. European Journal of Personality, $32,221-232$.

Boomsma, D. I., Busjahn, A., \& Peltonen, L. (2002). Classical twin studies and beyond. Nature Reviews Genetics, 3, 872-882.

Boomsma, D. I., De Geus, E. J., Vink, J. M., Stubbe, J. H., Distel, M. A., Hottenga, J. J., ... Willemsen, G. (2006). Netherlands twin register: from twins to twin families. Twin Research and Human Genetics, 9, 849-857. 
Brix, J., Pupeter, M., Rysina, A., Steinacker, G., Schneekloth, U., Baier, T., Gottschling, J., .. \& S Spinath, F. (2017). A longitudinal twin family study of the life course and individual development (TWINLIFE): Data collection and instruments of wave 1 face-to-face interviews (TwinLife Technical Report Series, 05). Bielefeld/Saarbrücken, Germany: Universität Bielefeld and Universität des Saarlandes.

Brïderl, J., Drobnič, S., Hank, K., Huinink, J., Nauck, B., Neyer, F. J., . . Wilhelm, B. (2018). The German Family Panel (pairfam). Cologne, Germany: GESIS Data Archive. doi:10.4232/pairfam.5678.9.1.0.

Busjahn, A. (2013). The Berlin twin registry for health research. Twin Research and Human Genetics, 16, 163-166.

Destatis. (2014). Mikrozensus 2013: Qualitätsbericht. Wiesbaden, Germany.

Diewald, M., Riemann, R., Spinath, F. M., Gottschling, J., Hahn, E., Kornadt, A. E., ... Weigel, L. (2019). TwinLife. GESIS Data Archive. ZA6701. https:// doi.org/10.4232/1.13208

Gil-Hernández, C. J. (2019). Do well-off families compensate for low cognitive ability? Evidence on social inequality in early schooling from a twin study. Sociology of Education, 92, 150-175.

Goebel, J., Grabka, M. M., Liebig, S., Kroh, M., Richter, D., Schröder, C., \& Schupp, J. (2018). The German Socio-Economic Panel Study (SOEP). Journal of Economics and Statistics, 239, 345-360.

Goldsmith, H. H. (1991). A zygosity questionnaire for young twins: A research note. Behavior Genetics, 21, 257-269.

Gottschling, J. (2017). Documentation TwinLife data: Cognitive abilities (TwinLife Technical Report Series, 02). Bielefeld and Saarbrücken, Germany: Universität Bielefeld and Universität des Saarlandes.

Gottschling, J., Hahn, E., Beam, C. R., Spinath, F. M., Carroll, S., \& Turkheimer, E. (2019). Socioeconomic status amplifies genetic effects in middle childhood in a large German twin sample. Intelligence, 72, 20-27.

Hahn, E., Gottschling, J., Bleidorn, W., Kandler, C., Spengler, M., Kornadt, A. E., ... Spinath, F. M. (2016). What drives the development of social inequality over the life course? The German TwinLife Study. Twin Research and Human Genetics, 19, 659-672.

Hahn, E., Gottschling, J., \& Spinath, F. M. (2013). Current twin studies in Germany: Report on CoSMoS, SOEP, and ChronoS. Twin Research and Human Genetics, 16, 173-178.

Haworth, C. M., Davis, O. S., \& Plomin, R. (2013). Twins Early Development Study (TEDS): A genetically sensitive investigation of cognitive and behavioral development from childhood to young adulthood. Twin Research and Human Genetics, 16, 117-125.

Hufer, A., Kornadt, A. E., Kandler, C., \& Riemann, R. (2019). Genetic and environmental variation in political orientation in adolescence and early adulthood: A nuclear twin family analysis. Journal of Personality and Social Psychology. Advance online publication. https://doi.org/10.1037/ pspp0000258

Huinink, J., Brüderl, J., Nauck, B., Walper, S., Castiglioni, L., \& Feldhaus, M. (2011). Panel analysis of intimate relationships and family dynamics (pairfam): Conceptual framework and design. Journal of Family Research, 23, 77-101.

Johnson, W., Hahn, E., Gottschling, J., Lenau, F., Spinath, F. M., \& McGue, M. (2018). SES-of-origin and BMI in youth: Comparing Germany and Minnesota. Behavior Genetics, 49, 1-25.
Kandler, C., Riemann, R., Spinath, F. M., Bleidorn, W., Thiel, W., \& Angleitner, A. (2013). The Bielefeld Longitudinal Study of Adult Twins (BiLSAT). Twin Research and Human Genetics, 16, 167-172.

Kandler, C., Waaktaar, T., Mõttus, R., Riemann, R., \& Torgersen, S. (2019). Unravelling the interplay between genetic and environmental contributions in the unfolding of personality differences from early adolescence to young adulthood. European Journal of Personality, 33, 221-244.

Keller, M. C., Medland, S. E., \& Duncan, L. E. (2010). Are extended twin family designs worth the trouble? A comparison of the bias, precision, and accuracy of parameters estimated in four twin family models. Behavior Genetics, 40, 377-393.

Klassen, L., Eifler, E. F., Hufer, A., \& Riemann, R. (2018). Why do people differ in their achievement motivation? A nuclear twin family study. Primenjena Psihologija, 11, 433-450.

Kornadt, A. E., Hufer, A., Kandler, C., \& Riemann, R. (2018). On the genetic and environmental sources of social and political participation in adolescence and early adulthood. Plos One, 13, 1-16.

Lang, V., \& Kottwitz, A. (2017). The sampling design and socio-demographic structure of the first wave of the TwinLife Panel Study: A comparison with the Microcensus (TwinLife Technical Report Series, 03). Bielefeld and Saarbrücken, Germany: Universität Bielefeld and Universität des Saarlandes.

Lenau, F., Hahn, E., Peters, A.-L., Gottschling, J., Thiel, W., \& Spinath, F. M. (2017). Zygosity determination in twin studies: A validation of zygosity questionnaires using DNA in the German TwinLife Study (TwinLife Working Paper Series, 01). Bielefeld and Saarbrücken, Germany: Universität Bielefeld and Universität des Saarlandes.

Lykken, D. T., McGue, M., \& Tellegen, A. (1987). Recruitment bias in twin research: The rule of two-thirds reconsidered. Behavior Genetics, 17, 343-362.

Magnusson, P. K., Almqvist, C., Rahman, I., Ganna, A., Viktorin, A., Walum, H., ... Larsson, H. (2013). The Swedish twin registry: Establishment of a biobank and other recent developments. Twin Research and Human Genetics, 16, 317-329.

Mattheus, S., Starr, A., Kornadt, A., \& Riemann, R. (2017). Documentation TwinLife data: Report cards (TwinLife Technical Report Series, 04). Bielefeld and Saarbrücken, Germany: Universität Bielefeld and Universität des Saarlandes.

Oniszczenko, W., Angleitner, A., Strelau, J., \& Angert, T. (1993). The Questionnaire of twins' physical resemblance (Unpublished report). Warsaw, Poland: Department of Psychology, University of Warsaw.

Schulz, W., Schunck, R., Diewald, M., \& Johnson, W. (2017). Pathways of intergenerational transmission of advantages during adolescence: Social background, cognitive ability, and educational attainment. Journal of Youth and Adolescence, 46, 2194-2214.

Spector, T. D., \& Williams, F. M. (2006). The UK adult twin registry (TwinsUK). Twin Research and Human Genetics, 9, 899-906.

Weiß, R. H. (2006). CFT 20-R. Grundintelligenztestskala 2. Manual. Göttingen, Deutschland: Hogrefe.

Weiß, R. H., \& Osterland, J. (2012). Grundintelligenttest Skala 1 - Revision: CFT 1-R. Göttingen, Deutschland: Hogrefe.

Weinschenk, A. C., Dawes, C. T., Kandler, C., Bell, E., \& Riemann, R. (2019). New evidence on the link between genes, psychological traits, and political engagement. Politics and the Life Sciences, 38, 1-13. 